\title{
Optimization of genetic gain in different variables for Eucalyptus grandis Hill ex Maiden breeding
}

\author{
Otimização do ganho genético em diferentes variáveis para o \\ melhoramento do Eucalyptus grandis Hill ex Maiden \\ Thiago Wendling Gonçalves de Oliveira ${ }^{1}$ (D), Antonio Rioyei Higa ${ }^{1}$ (D), Luciana Duque Silva² (B) \\ 'Universidade Federal do Paraná - UFPR, Curitiba, PR, Brasil \\ 2Universidade de São Paulo -USP, Escola Superior de Agricultura “Luiz de Queiroz" - ESALQ, Piracicaba, SP, Brasil
}

\begin{abstract}
How to cite: Oliveira, T. W. G., Higa, A. R., \& Silva, L. D. (2021). Optimization of genetic gain in different variables for Eucalyptus grandis Hill ex Maiden breeding. Scientia Forestalis, 49(132), e3741. https://doi.org/10.18671/scifor.v49n132.17
\end{abstract}

\begin{abstract}
This study aimed to optimize the genetic gain for initial growth, low rust infection, and wood quality in an open pollination progeny test of E. grandis. The progeny test was established in Anhembi-SP, in a randomized block design, with 176 progenies, single tree plots, 29 replications, and one external borderline. Three evaluations were carried out. For the variable related to growth, diameter at breast height (DBH); evaluation at 20 months of age; for the degree of rust infection (DRI) the evaluations were carried out at 9 months of age, and for wood quality the variable number of branches (NB) was evaluated at 14 months. The choice of these variables considered the estimates of heritability and genetic correlations. Eight selection methods were used to optimize genetic gains for each variable, such as indirect selection, independent levels, and combined selection indexes with equal and different weights for each variable. The breeding strategies were based on the formation of Seedling Seed Orchards (SSO) and Clonal Seed Orchards (CSO). Based on the results, the indirect selection was not recommended because genetic correlations between $\mathrm{DBH}, \mathrm{DRI}$, and NB were weak $(<0.50)$, and it was necessary to consider the three variables for the construction of selection indexes and independent levels. For both breeding strategies the independent selection levels were the best in optimizing simultaneous selection for growth, rust resistance, and wood quality; with gains for DBH, DRI, and NB of 5.83\%, $13.88 \%$, and $4.12 \%$, respectively for the formation of SSOs; while gains of $7.23 \%, 18.76 \%$, and $6.72 \%$ were calculated respectively for the formation of CSOs.
\end{abstract}

Keywords: Forest breeding; Genetic correlation; Selection indexes; Independent levels.

\section{Resumo}

Este estudo teve como objetivo otimizar o ganho genético para crescimento inicial, infecção à ferrugem e qualidade da madeira em teste de progênies de polinização aberta de $E$. grandis. O teste de progênies foi estabelecido em Anhembi-SP, delineamento de blocos casualizados, com 176 progênies, uma planta por parcela, 29 repetições e uma linha de bordadura externa. Três avaliações foram realizadas. Para a variável relacionada ao crescimento foi escolhido o diâmetro à altura do peito (DAP) avaliado aos 20 meses de idade, para o grau de infecção à ferrugem (DRI) as avaliações foram feitas aos 9 meses de idade e para a qualidade da madeira, a variável número de galhos (NB) foi avaliada aos 14 meses de idade. A escolha dessas variáveis considerou as estimativas de herdabilidade e correlações genéticas. Oito métodos de seleção foram usados para otimizar os ganhos genéticos para cada variável, a seleção indireta, níveis independentes e índices de seleção combinados com pesos iguais e diferentes para cada variável. As estratégias de melhoramento foram baseadas na formação de um Pomar de Sementes por Mudas (SSO) e um Pomar Clonal de Sementes (CSO). Com base nos resultados, a seleção indireta não foi recomendada, pois as correlações genéticas entre DAP, DRI e NB foram fracas $(<0,50)$, sendo necessário considerar as três variáveis para a construção

Financial support: None.

Conflict of interest: Nothing to declare.

Corresponding author: thiago.wgdeoliveira@gmail.com

Received: 25 June 2021.

Accepted: 03 November 2021.

Editor: Mauro Valdir Schumacher

(i) This is an Open Access article distributed under the terms of the Creative Commons Attribution License, which permits unrestricted use,

c) distribution, and reproduction in any medium, provided the original work is properly cited. 
dos índices de seleção e níveis independentes. Para ambas as estratégias, os níveis de seleção independente são os que melhor otimizam a seleção simultânea para crescimento, resistência à ferrugem e qualidade da madeira, com ganhos para DAP, DRI e NB de 5,83\%, 13,88\% e 4,12\%, respectivamente, para a formação do SSO, e ganhos de 7,23\%, 18,76\% e 6,72\%, respectivamente, para a formação do CSO.

Palavras-chave: Melhoramento florestal; Correlação genética; Índices de seleção; Níveis independentes.

\section{INTRODUCTION}

Eucalyptus grandis Hill ex Maiden is one of the main species used for paper, pulp and sawn logs production due to its high growth, adequate wood density and good stem straightness. However, the use of the species for sawn logs should consider some aspects, such as the presence of wood defects like knots (Polli et al., 2006) and the high susceptibility of some genotypes to diseases, especially in the early stages of development such as eucalyptus rust caused by the fungus Puccinia psidii Winter, which affects the initial productivity (Miranda et al., 2013).

In Brazil, genetic materials of $E$. grandis are greatly influenced by provenance, and genotypes originating from Coff's Harbor in New South Wales, Australia, were the ones that presented the best growth rates and low tolerance to frost. The provenances from Atherton in Queensland, Australia, were more susceptible to fungal diseases, such as rust. However, they had greater survival in areas with water deficit (Eldridge et al., 1993).

The production of improved genetic materials by seeds or vegetative propagation caused an increase in productivity and adaptability to biotic and abiotic stress (Gonçalves et al., 2013). Seed orchards make the use of improved seeds from selected progenies and individuals possible (Baudouin et al., 1997; Nichols et al., 2010). Forest breeding for sawn logs should optimize genetic gain to obtain better progenies or individuals, and the variables need simultaneous selection for lower incidence of diseases, higher wood quality, and productivity.

Therefore, considering productivity, breeding programs for sawn logs should prioritize the diameter at breast height (DBH), as it presents moderate heritability values and greater genetic correlation with wood volume (Volker et al., 1990; Paula et al., 2002), an important characteristic for the use of sawn wood. Among the diseases, eucalyptus rust is one of the most important, since the great genetic variability and good genetic control for susceptibility to fungus $P$. psidii in E. grandis (Miranda et al., 2013) showed the possibility of obtaining high genetic gains with the selection of the most resistant progenies, avoiding the decrease in productivity and damage to young plantations (Rodas et al., 2015). Another aspect is knot presence in the wood, which is one of the main defects in sawn timber production. This defect depends on the knot size, amount and location in the tree trunk. Therefore, for higher quality timber one should use variables related to the number and size of branches on the stem (Kretschmann, 2010).

The optimization of genetic gain depends on adequate selection methods, through which is possible to select genotypes that have several favorable characteristics simultaneously, while considering genetic parameters such as heritability and correlations (Vencovsky \& Barriga, 1992; Rezende et al., 2014). Heritability influences the choice of the most promising variables for selection; and genetic correlations show the degree of relationship between two traits. If there are strong genetic correlations $(<0.70)$ indirect selection methods are advantageous (Falconer, 1976). The concept of optimization of genetic gain originated in animal breeding, after seeking a balance between genetic gain for different variables for populations and individuals (Villanueva \& Woolliams, 1997).

By choosing the appropriate selection method, it is possible to optimize the gain for different variables, such as independent levels and selection indexes. Independent level is a selection method in which elimination levels are established for each variable. Thus, the method eliminates all families and individuals below this level, being interesting for variables that show no strong correlations (Resende, 2005). The selection indices, through the correct weighting of their coefficients, provide greater total genetic gains, with adequate distribution of gain among the variables according to the purposes of breeding (Smith et al., 1981). However, a difficulty to use selection indices occurs if there are weak genetic correlations and also in establishing economic weights. 
We aimed to optimize the genetic gain for the formation of a Seedling Seed Orchard (SSO) and a Clonal Seed Orchard (CSO) for variables related to the degree of rust infection (DRI), the number of branches (NB), and initial growth in diameter at breast height (DBH) in E. grandis progenies. The hypothesis is that indirect selection will bring lower genetic gains than simultaneous selection methods, such as selection indices and independent levels, and that the combination of different variables will allow the selection of superior families for the commercial genetic materials used in this study.

\section{MATERIAL AND METHODS}

The progeny test in this study was planted in August 2014 at the Experimental Station of Forest Sciences of Superior School of Agriculture "Luiz de Queiroz" (ESALQ) of the University of São Paulo (USP), in the city of Anhembi, São Paulo state, Brazil. The soil is classified as Entisols. The mean temperature was $22.4^{\circ} \mathrm{C}$ and annual precipitation of $1336.8 \mathrm{~mm}$. According to the Köppen classification the climate is Tropical with dry winter (Aw) (Alvares et al., 2013).

The genetic test was established in a completely randomized block design with 29 replicates, one plant per plot, 176 open-pollinated progenies of Eucalyptus grandis, with $3 \mathrm{~m} \times 2 \mathrm{~m}$ spacing and one external borderline (for further details see Oliveira et al., 2018). The origin of E. grandis progenies was from the Clonal Seed Orchard (CSO) in the city of Itapeva, São Paulo state, Brazil. The plants of this orchard were selected from plantations originated from seeds collected in the region of Atherton, Queensland, Australia. Nutrient additions were applied to eliminate any nutritional deficits. At planting $200 \mathrm{~kg} \mathrm{ha}^{-1}$ of NPK (06-30-06), $17 \mathrm{~kg} \mathrm{ha}^{-1}$ of FTE Br 12 (mixture composed of slow solubility of micronutrients) were applied in addition to $2 \mathrm{t} \mathrm{ha-1}$ of dolomitic limestone. Three months after planting ammonium sulfate $\left(68 \mathrm{~kg} \mathrm{ha}^{-1}\right)$, borogan $\left(5 \mathrm{~kg} \mathrm{ha}^{-1}\right)$ and potassium chloride (140 $\left.\mathrm{kg} \mathrm{ha}^{-1}\right)$ was added.

In addition to the E. grandis progenies described above, two commercial E. grandis of seed origin were also used, the first coming from a second-generation Seed Production Area (SPA) in Itatinga (IT059), São Paulo state, Brazil, and the second coming from a first-generation Seedling Seed Orchard (SOS) in Anhembi (AN213) São Paulo state, Brazil. These plants originated from Coff's Harbour, New South Wales, Australia. The third material was a commercial clone of E. urophylla named AEC 0144 in the "Registro Nacional de Cultivares do Ministério do Agricultura, Pecuária e Abastecimento - MAPA". Data from the commercial materials were not used in genetic parameter estimations, but were used only in the ranking of the best families in the selection methods.

The degree of rust infection (DRI) was assessed at 9 months of age, using the scale established by Zamprogno et al. (2008) with modification by the authors: 1 - plants with intense pustules and sporulation, compromising the leaf structure of the plant; 2 - with abundant pustules and sporulation; 3 - with few pustules and spaced sporulation; 4 - with the absence of pustules and sporulation. The number of branches (NB) was evaluated at 14 months of age, establishing a sub-sample in the tree stem between 1 and $2 \mathrm{~m}$ height, where all branches present in this sub-sample were counted. The diameter at breast height (DBH) was evaluated at 20 months of age with at $1.30 \mathrm{~m}$ on the tree stem. The estimation of genetic parameters is detailed in the study of Oliveira et al. (2018) and presented in Table 1.

Table 1. Individual additive heritability $\left(h^{2}{ }_{a}\right)$, heritability of progenies $\left(h^{2} \mathrm{mp}\right)$, heritability within progenies $\left(h^{2}{ }_{a d}\right)$, progeny selection accuracy $\left(r_{a a}\right)$, and overall mean for the degree of rust infection at 9 months of age (DRI), the number of branches at 14 months (NB) and diameter at $1.3 \mathrm{~m}$ height at 20 months (DBH) for the calculation of genetic gains in the E. grandis progeny test in Anhembi, São Paulo.

\begin{tabular}{cccc}
\hline Genetic parameters & DRI & NB & DBH (cm) \\
\hline $\mathrm{h}^{2}{ }_{\mathrm{a}}$ & $0.48 \pm 0.05$ & $0.19 \pm 0.03$ & $0.14 \pm 0.03$ \\
$\mathrm{~h}^{2} \mathrm{mp}$ & 0.79 & 0.59 & 0.52 \\
$\mathrm{~h}^{2}{ }_{\mathrm{ad}}$ & 0.41 & 0.15 & 0.11 \\
$\mathrm{r}_{\mathrm{aa}}$ & 0.89 & 0.77 & 0.72 \\
Overrall mean & 2.62 & 13.4 & 8.06 \\
\hline
\end{tabular}

Source: Oliveira et al. (2018). 
Matrices of genetic and phenotypic covariances and genetic and phenotypic correlations between DRI, NB, and DBH were estimated using the SELEGEN-Relm/Blup software (Resende, 2002b) to determine the weighting coefficients of the selection indices: $\operatorname{COV}(X, Y)=\frac{1}{n}\left[\sum_{i=1}^{n} x_{i} y_{i}-\frac{1}{n}\left(\sum_{i=1}^{n} x_{i}\right)\left(\sum_{i=1}^{n} y_{i}\right)\right]$, where $\operatorname{COV}(X, Y)=$ genetic or phenotypic covariance between $\mathrm{X}$ and $\mathrm{Y}, n=$ number of observations, $x_{i}=$ additive genetic or phenotypic values of the variable $\mathrm{X}$ and $y_{i}=$ additive genetic or phenotypic values of variable $\mathrm{Y}$. The genetic correlations were determined as: $r_{a(x, y)}=\frac{\operatorname{COV}_{a(x, y)}}{\sigma_{a x}+\sigma_{a y}}$, where $r_{a(x, y)}=$ additive genetic correlation between $\mathrm{x}$ and $\mathrm{y}, \operatorname{COV}_{a(x, y)}=$ additive genetic covariance between $\mathrm{x}$ and $\mathrm{y}, \sigma_{a x}=$ additive genetic standard deviation for $\mathrm{x}$ and $\sigma_{a y}=$ additive genetic standard deviation for $\mathrm{y}$. Genetic correlations were classified according to Calvo (2004), adapted by the authors, into weak $(<0.50)$, moderate $(0.50$ to 0.70$)$, and strong $(>0.70)$.

Two selection indices were used to select superior families and individuals for the lower GRI, lower NB, and higher DBH, simultaneously. To unify the scale between the three variables, NB and DBH were transformed into categorical variables, ranging from 1 to 4 , as the GRI (Table 2):

Table 2. Classes of the degree of rust infection (DRI) and the amplitude of classes for the number of branches (NB) and diameter at 1.3 height $(\mathrm{DBH})$.

\begin{tabular}{cccc}
\hline Class & DRI & NB & DBH $(\mathbf{c m})$ \\
\hline 1 & 1 & 21 a 25 & 0.0 a 3.8 \\
2 & 2 & 16 a 20 & 3.9 a 7.7 \\
3 & 3 & 11 a 15 & 7.8 a 11.6 \\
4 & 4 & 5 a 10 & 11.7 a 15.6 \\
\hline
\end{tabular}

The NB ranged from 5 to 25 branches and was divided into four classes, with an amplitude of 5 branches, where individuals with the lowest number of branches were classified with the highest score (4). The DBH ranged from 0.0 to $15.6 \mathrm{~cm}$ and was also divided into four classes of $3.8 \mathrm{~cm}$ of amplitude, where individuals with higher DBH were also classified in the highest score (4).

The classic selection index, proposed by Smith (1936) and Hazel (1943) was used, which consists of the linear combination of variables of economic importance, to maximize the correlation between the index $(\mathrm{I})$ and the genotypic aggregate $(\mathrm{H})$, and the determination of the weighting coefficients of the index follow according to the equation: $b=P^{-1} G w$, where $b=$ vector of weighting coefficients of the classic index, $P^{-1}=$ inverse of the matrix of phenotypic variances and covariances between variables, $G=$ matrix of genetic variances and covariances between variables, and $w=$ vector of previously established economic weights. The equation presented above derives from maximizing the correlation between any index (I) and the genotypic aggregate $(\mathrm{H})$ for the variables used in the construction of the index, according to equations: $\quad I=b_{1} x_{1}+b_{2} x_{2}+\ldots+b_{n} x_{n}=\sum_{i=1}^{n} b_{i} x_{i}=b^{\prime} x^{\prime}, \quad H=w_{1} g_{1}+w_{2} g_{2}+\ldots+w_{n} g_{n}=\sum_{i=1}^{n} a_{i} g_{i}=w^{\prime} g^{\prime} \quad$ and $\rho_{I H}=\frac{b^{\prime} G w}{\sqrt{\left(b^{\prime} P b\right)\left(w^{\prime} G w\right)}}$, where $g^{\prime}=n \times p$ dimension matrix of unknown genetic values of the $n$ variables considered; $x^{\prime}=n \times p$ dimension matrix of variable means, $w^{\prime}=n \times 1$ dimension vector of previously established economic weights, $b^{\prime}=n \times 1$ dimension vector of index weighting coefficients, $n=$ number of evaluated variables, $p=$ number of families or progenies evaluated and $\rho_{I H}=$ correlation between I and $\mathrm{H}$. 
Economic weights $(w)$ were calculated by multiplying the weight established for each variable by the value of the heritability of progenies estimated in the progeny test (Oliveira et al., 2018). To determine $w$, the economic importance and magnitude of the genetic parameters were taken into account, mainly due to the lower additive genetic value of some variables when compared to others, such as $\mathrm{DBH}$, which is related to growth and presented a lower heritability (Table 3). The matrix calculations used to find the Smith and Hazel index coefficients were performed in SAS software, using the PROC IML. The NB and DBH used to calculate the Smith and Hazel indices coefficients were the categorical variables ranging from 1 to 4 , as described previously.

Table 3. Percentage weights established for the degree of rust infection (DRI), the number of branches (NB), and diameter at $1.3 \mathrm{~m}$ height (DBH) to calculate the coefficients of Smith and Hazel selection indices and the Pesek and Barker selection indices in the E. grandis progeny test in Anhembi, São Paulo.

\begin{tabular}{ccc}
\hline Variables & Weights \\
\hline DRI & $33.3 \%$ & $10 \%$ \\
NB & $33.3 \%$ & $40 \%$ \\
DBH (cm) & $33.4 \%$ & $50 \%$ \\
Soma & $100 \%$ & $100 \%$ \\
\hline
\end{tabular}

The Pešek \& Baker (1969) index was also used, known as the index of the desired gains, where the economic weights $(w)$ were replaced by the desired gains $\left(\Delta g_{d}\right)$ in the breeding program: $b=G^{-1} \Delta g_{d}$, where $b=$ vector of weighting coefficients of the desired gain index, $G^{-1}=$ inverse of the matrix of genetic variances and covariances between the variables and $\Delta g_{d}=$ vector of desired gains established by the breeder.

The index coefficient estimation follows according to the expression of the expected gain for each variable: $\Delta g=\frac{G b i}{\sigma_{I}}$, where $\Delta g=$ expected gains vector, $i=$ selection intensity and $\sigma_{i}=$ index standard deviation. Pešek \& Baker (1969) replace the vector $\Delta g$ in the previous expression, which is of expected gains, by the vector $\Delta g_{d}$, which is the vector of desired gains. The scalar value $\left(\frac{\sigma_{I}}{i}\right)$ does not affect the proportionality of the $b$ values, therefore, $\left(\frac{\sigma_{I}}{i}\right)$ was taken from the equation above for the determination index coefficients.

The same approach of estimating $w$ in the Smith and Hazel indices was used to determine the $\Delta g_{d}$ of the Pesek and Baker indices, where the weights in Table 3 were multiplied by the heritability of progeny of each variable. The matrix calculations used to find the coefficients of the Pesek and Baker index were performed in SAS software, using the PROC IML.

Additive genetic values of individuals and families through the selection indices described above were determined with the model: $y=X b+Z a+e$ in SELEGEN-REML/BLUP software (Resende, 2002b), where $y=$ vector of data, $b=$ vector of blocks effects added to the overall mean (assumed as fixed), $a=$ vector of individual additive genetic effects (assumed as random), $e=$ vector of errors or residuals (random), and $X, Z=$ matrices of mentioned effects. This mixed linear model is used for the evaluation of open-pollinated progenies, in a randomized block design, with one plant per plot, one measurement per individual, one variable, and one population.

The selection by independent levels was made first for $\mathrm{DBH}$, where $55 \%$ of the worst families were eliminated, then for NB, where $30 \%$ of the worst families were eliminated and finally for DRI, $13 \%$ of the worst families were eliminated. The same elimination levels were used for selection within progenies, where the selection was made for $\mathrm{DBH}$, then for $\mathrm{NB}$, and finally for DRI. The variable order in independent levels considered the heritability values (Table 1).

Two breeding strategies by seed were established considering short- and medium-term improvement, where the effective population size $(\mathrm{Ne})$ was calculated with the expression presented below (Resende, 2002a): 
$N e=\frac{4 N_{f} k_{f}}{k_{f}+3}$, where $N e=$ effective population size, $N_{f}=$ number of selected families and $k_{f}=$ number of selected individuals per family.

The short-term strategy was the formation of a Seedling Seed Orchard (SSO), with the selection of the 80 best families $(i=45 \%)$ and the 5 best individuals within the best families $(i=17 \%)$. The selection within the families was made based on the grouping of individuals' information within blocks, thus selecting the individual with the highest additive genetic value grouping blocks 1 to 6 , blocks 7 to 12 , blocks 13 to 18 , blocks 19 to 24 , and blocks 25 to 29 , since operationally for the transformation of the progeny test into an SSO it will be necessary to reduce the number of blocks due to the number of plants per plot (one). The medium-term strategy was the formation of a Clonal Seed Orchard (CSO) with higher selection intensity between and within families. The calculation of genetic gains was made based on the selection of the best individual $(i=3 \%)$ from the 50 best families in the progeny test $(i=28 \%)$. Direct selection for DRI, NB, and DBH in the two breeding strategies was used for comparison with independent levels and selection indices. Through direct selection for each variable, we also calculated the gain with the indirect selection of the other variables (Table 4).

Table 4. Selection methods for calculating genetic gains in the E. grandis progeny test in Anhembi, São Paulo

\begin{tabular}{cc}
\hline Method & Description \\
\hline 1 & Direct selection for DRI \\
2 & Direct selection for NB \\
3 & Direct selection for DBH \\
4 & Smith and Hazel selection index with equal weights among variables \\
5 & Smith and Hazel selection index with different weights among variables \\
6 & Pesek and Baker selection index with equal weights among variables \\
7 & Pesek and Baker selection index with different weights between variables \\
8 & Independent levels \\
\hline
\end{tabular}

$\mathrm{DRI}=$ degree of rust infection; NB = number of branches e $\mathrm{DBH}=$ diameter at $1.3 \mathrm{~m}$ height.

The genetic gains were determined using the following expressions (Cruz et al., 2004): $G S$ between $=h_{m p}^{2} * D S_{f}$, where $G S$ between = genetic gain by selection among families; $h_{m p}^{2}=$ average heritability of progenies, $D S_{f}=$ selection differential between families. The $D S_{f}$ is calculated using: $D S_{f}=\left(\bar{X}_{f}-\bar{X} O\right)$, where $\bar{X} f_{s}=$ mean of selected families and $\bar{X}_{o}=$ mean of the original population. The percentage genetic gain was calculated: GSbetween $(\%)=\frac{G \text { Sbetweeen } * 100}{\bar{X}_{o}}$, where GSentre $(\%)=$ percentage of genetic gain by selection among families .

The genetic gain with within-family selection ( GS within) was calculated in the same way as GSbetween, using additive heritability within progenies $\left(h_{a d}^{2}\right)$ and family mean $(\bar{X} f)$ in calculating the within selection differential of families. The percentage genetic gain was calculated: $\operatorname{GS}$ within $(\%)=\frac{G S \text { within } * 100}{\bar{X} f}$, where $\operatorname{GS}$ within $(\%)=$ percentage of genetic gain by selection within the family. As the breeding strategies will select several families, the mean GS within $(\%)$ was calculated using the expression: $\overline{G S}$ within $(\%)=\frac{\sum G S \text { within }(\%)}{n f}$, where $\overline{G S}$ within $(\%)=$ mean genetic gain within the family selection and $n f=$ number of selected families. The total genetic gain was calculated through the expression: GStotal $(\%)=$ GS between $(\%)+\overline{G S}$ within $(\%)$, where $\operatorname{GStotal}(\%)=$ percentage of total genetic gain by selection between and within families. 


\section{RESULTS AND DISCUSSION}

The economic weights $(w)$ in the Smith and Hazel index coefficients and the desired gains $\left(\Delta g_{d}\right)$ in the Pesek and Baker index coefficients varied among GRI, NB, and DBH; and when considered equal weights among variables the highest value was observed for the variable that presented high heritability (GRI) (Table 5).

Table 5. Values of economic weights $(w)$ and value of desired gains $(\Delta g d)$ for the calculation of the coefficients by the two selection indexes of Smith and Hazel and the Pesek and Barker considering equal weights between the variables (selection index 1) and weight differences between the variables (selection index 2).

\begin{tabular}{ccc}
\hline Variáveis & Selection index 1 & Selection index 2 \\
\hline DRI & 26.65 & 7.99 \\
NB & 19.99 & 23.99 \\
DBH $(\mathrm{cm})$ & 17.65 & 26.47
\end{tabular}

$\overline{\mathrm{DRI}}=$ degree of rust infection; $\mathrm{NB}=$ number of branches e $\mathrm{DBH}=$ diameter at $1.3 \mathrm{~m}$ height.

The highest weighting coefficients of Smith and Hazel indices were estimated for DRI, even when the economic weight for this variable was lower, as well as the Pesek and Baker index that considered an equal level of importance for DRI, NB, and DBH (method 6). The opposite occurred for the Pesek and Baker index, which is considered the highest level of importance for DBH (method 7) (Table 6).

Table 6. Selection index coefficients for the degree of rust infection (DRI), number of branches (NB), and diameter at $1.3 \mathrm{~m}$ height (DBH) used in the E. grandis progeny test in Anhembi, São Paulo.

\begin{tabular}{|c|c|c|c|c|}
\hline \multirow{2}{*}{$\begin{array}{l}\text { Selection } \\
\text { Methods }\end{array}$} & \multirow{2}{*}{ Description } & \multicolumn{3}{|c|}{ Index coefficients } \\
\hline & & DRI & NB & DBH \\
\hline 4 & $\begin{array}{l}\text { Smith and Hazel selection index with } \\
\text { equal weights among variables }\end{array}$ & 13.8798 & 1.8718 & 0.1387 \\
\hline 5 & $\begin{array}{l}\text { Smith and Hazel selection index with } \\
\text { different weights among variables }\end{array}$ & 8.0052 & 2.2662 & 0.9806 \\
\hline 6 & $\begin{array}{l}\text { Pesek and Baker selection index with } \\
\text { equal weights among variables }\end{array}$ & 101.9076 & 35.4345 & 11.9855 \\
\hline 7 & $\begin{array}{l}\text { Pesek and Baker selection index with } \\
\text { different weights between variables }\end{array}$ & -15.7816 & 52.7954 & 76.3324 \\
\hline
\end{tabular}

Genetic correlations between DRI, NB, and DBH were weak $(<0.50)$, and variables evaluated in the E. grandis progeny test were independent (Table 7). Balmelli et al. (2014) also observed weak and negative correlations between leaf disease severity and growth (DBH and height), which ranged from -0.40 to -0.20 , and between disease severity and survival $(-0.51$ to -0.28$)$, indicating that disease severity is uncorrelated with these variables. Weak genetic correlations between DBH and other wood quality traits, such as stem shape and bifurcation, were also observed in the study of Macedo et al. (2013) with E. tereticornis (0.25) and the study of Hamilton et al. (2015) with E. globulus (0.17).

Table 7. Genetic correlation at individual plant level between degree rust infection (DRI), number of branches (NB), and diameter at $1.3 \mathrm{~m}$ height (DBH) in the E. grandis progeny test in Anhembi, São Paulo.

\begin{tabular}{cccc}
\hline \multicolumn{4}{c}{ Genetic correlation } \\
\hline Variables & DRI & NB & DBH \\
\hline DRI & 1 & - & - \\
NB & -0.08 & 1 & - \\
DBH & 0.49 & -0.33 & 1
\end{tabular}

$\mathrm{DRI}=$ degree of rust infection; $\mathrm{NB}=$ number of branches e $\mathrm{DBH}=$ diameter at $1.3 \mathrm{~m}$ height. 
Since we observed weak correlations, to select trees with a lower DRI, greater growth in $\mathrm{DBH}$, and with lower NB for a better quality of sawn logs in this first stage of the $E$. grandis breeding program, selection methods that better match the weighting between variables must be necessary in order to select the best families and/or individuals.

Selection intensities between and within progenies for SSO maintained an effective population size of 200 and genetic variability for the next stages of the breeding program (Resende \& Bertolucci, 1995). Table 8 shows the ranking of the best 80 progenies among the E. grandis families and the commercial materials in the progeny test for each selection method.

Table 8. E. grandis progenies and commercial materials selected by direct selection for DRI (method 1), direct selection for NB (method 2), direct selection for DBH (method 3), selection indexes (methods 4, 5, 6, and 7), and independent levels (method 8).

\begin{tabular}{|c|c|c|c|c|c|c|c|c|}
\hline $\begin{array}{l}\text { Selection } \\
\text { Methods }\end{array}$ & 1 & 2 & 3 & 4 & 5 & 6 & 7 & 8 \\
\hline Ranking & DRI & NB & DBH & SH & SH & PB & PB & NI \\
\hline 1 & AEC144 & 148 & AEC144 & AEC144 & AEC144 & AEC144 & AEC144 & 1 \\
\hline 2 & 36 & 102 & 117 & 36 & 36 & 36 & 117 & 9 \\
\hline 3 & 71 & 87 & 51 & 71 & 71 & 71 & 87 & 13 \\
\hline 4 & 168 & AEC144 & 87 & 50 & 50 & 50 & 183 & 14 \\
\hline 5 & 179 & 101 & 81 & 168 & 168 & 168 & 102 & 20 \\
\hline 6 & 104 & 48 & 84 & 179 & 179 & 179 & 81 & 25 \\
\hline 7 & 50 & 182 & 116 & 67 & 67 & 67 & 90 & 26 \\
\hline 8 & 35 & 127 & 50 & 35 & 35 & 20 & 115 & 28 \\
\hline 9 & 9 & 117 & 102 & 9 & 20 & 35 & 116 & 29 \\
\hline 10 & 20 & 118 & 20 & 104 & 175 & 175 & 99 & 33 \\
\hline 11 & 149 & 81 & 47 & 20 & 9 & 9 & 148 & 35 \\
\hline 12 & 67 & 55 & 106 & 78 & 78 & 78 & 51 & 36 \\
\hline 13 & 114 & 161 & 99 & 175 & 107 & 87 & 61 & 37 \\
\hline 14 & 175 & 43 & 183 & 107 & 87 & 107 & 55 & 41 \\
\hline 15 & 177 & 38 & 172 & 133 & 117 & 117 & 118 & 42 \\
\hline 16 & 105 & 40 & 33 & 149 & 133 & 133 & 43 & 45 \\
\hline 17 & 37 & 90 & 26 & 142 & 149 & 114 & 20 & 47 \\
\hline 18 & 133 & 61 & 126 & 114 & 142 & 142 & 127 & 48 \\
\hline 19 & 78 & 183 & 121 & 105 & 114 & 149 & 161 & 50 \\
\hline 20 & 107 & 115 & 75 & 87 & 104 & 104 & 26 & 51 \\
\hline 21 & 117 & 178 & 64 & 117 & 105 & 105 & 38 & 54 \\
\hline 22 & 180 & 144 & 61 & 177 & 37 & 37 & 1 & 55 \\
\hline 23 & 66 & 86 & 107 & 37 & 51 & 51 & 151 & 57 \\
\hline 24 & 87 & 62 & 175 & 172 & 177 & 177 & 75 & 58 \\
\hline 25 & 172 & 138 & 115 & 180 & 172 & 172 & 101 & 61 \\
\hline 26 & 11 & 1 & 71 & 51 & 180 & 180 & 182 & 62 \\
\hline 27 & 73 & 125 & 77 & 125 & 102 & 102 & 64 & 64 \\
\hline 28 & 33 & 114 & 17 & 54 & 176 & 125 & 163 & 66 \\
\hline 29 & 54 & 167 & 9 & 176 & 125 & 176 & 50 & 67 \\
\hline 30 & 126 & 142 & 90 & 33 & 47 & 47 & 71 & 70 \\
\hline 31 & 27 & 130 & 133 & 152 & 33 & 26 & 175 & 71 \\
\hline 32 & 142 & 26 & 181 & 47 & 26 & 66 & 28 & 72 \\
\hline 33 & 74 & 134 & 78 & 66 & 66 & 33 & 62 & 73 \\
\hline 34 & 125 & AN213 & 6 & 11 & 54 & 54 & 107 & 74 \\
\hline 35 & 51 & 176 & 13 & 27 & 152 & 113 & 126 & 75 \\
\hline 36 & 102 & 151 & 28 & 26 & 113 & 160 & 124 & 78 \\
\hline 37 & 10 & 57 & 161 & 73 & 160 & 156 & 134 & 80 \\
\hline 38 & 176 & 71 & 147 & 102 & 156 & 152 & 57 & 81 \\
\hline 39 & 128 & 165 & 66 & 113 & 27 & 165 & 106 & 87 \\
\hline 40 & 139 & 36 & 105 & 156 & 73 & 73 & 42 & 90 \\
\hline
\end{tabular}


Table 8. E. grandis progenies and commercial materials selected by direct selection for DRI (method 1), direct selection for NB (method 2), direct selection for DBH (method 3), selection indexes (methods 4, 5, 6, and 7), and independent levels (method 8).

\begin{tabular}{|c|c|c|c|c|c|c|c|c|}
\hline $\begin{array}{l}\text { Selection } \\
\text { Methods }\end{array}$ & 1 & 2 & 3 & 4 & 5 & 6 & 7 & 8 \\
\hline 41 & 28 & 20 & 41 & 25 & 165 & 27 & 14 & 96 \\
\hline 42 & 165 & 175 & 180 & 165 & 11 & 28 & 48 & 99 \\
\hline 43 & 106 & 39 & 118 & 160 & 139 & 138 & 47 & 101 \\
\hline 44 & 181 & 35 & 10 & 139 & 25 & 139 & 77 & 102 \\
\hline 45 & 47 & 27 & 74 & 128 & 28 & 11 & 176 & 106 \\
\hline 46 & 53 & 29 & 80 & 10 & 126 & 25 & 5 & 107 \\
\hline 47 & 84 & 75 & 151 & 74 & 138 & 126 & 33 & 112 \\
\hline 48 & 113 & 156 & 35 & 28 & 128 & 74 & AN213 & 113 \\
\hline 49 & 160 & 160 & 114 & 126 & 74 & 128 & 80 & 114 \\
\hline 50 & 52 & 16 & 59 & 138 & 136 & 136 & 138 & 115 \\
\hline 51 & 141 & 135 & 83 & 136 & 106 & 116 & 144 & 116 \\
\hline 52 & 152 & 14 & 148 & 106 & 116 & 106 & 59 & 117 \\
\hline 53 & 161 & 152 & 144 & 84 & 10 & 75 & 130 & 118 \\
\hline 54 & 25 & 143 & 113 & 181 & 75 & 10 & 114 & 130 \\
\hline 56 & 169 & 28 & 149 & 143 & 181 & 181 & 78 & 132 \\
\hline 57 & 136 & 158 & 176 & 6 & 84 & 183 & 181 & 133 \\
\hline 58 & 156 & 8 & 182 & 116 & 161 & 161 & 66 & 134 \\
\hline 59 & 13 & 113 & 169 & 75 & 183 & 143 & 160 & 135 \\
\hline 60 & 64 & 99 & 135 & 29 & 143 & 84 & 13 & 136 \\
\hline 61 & 96 & 37 & 168 & 77 & 99 & 99 & 147 & 138 \\
\hline 62 & 24 & 78 & 14 & 161 & 64 & 64 & 136 & 139 \\
\hline 63 & 70 & 173 & 130 & 18 & 77 & 130 & 84 & 140 \\
\hline 64 & 69 & 44 & 128 & 130 & 130 & 29 & 121 & 141 \\
\hline 65 & 130 & 149 & 163 & 13 & 29 & 77 & 172 & 142 \\
\hline 66 & 138 & 93 & 65 & 121 & 13 & 86 & 16 & 144 \\
\hline 67 & 75 & 136 & 85 & 64 & 86 & 13 & 149 & 148 \\
\hline 68 & 45 & 73 & AN213 & 122 & 121 & 121 & 17 & 149 \\
\hline 69 & 29 & 120 & 142 & 70 & 6 & 122 & 9 & 152 \\
\hline 70 & 85 & 124 & 179 & 86 & 122 & 69 & 65 & 156 \\
\hline 71 & 77 & 42 & 124 & 169 & 169 & 144 & 113 & 160 \\
\hline 72 & 88 & 140 & 36 & 99 & 69 & 169 & 140 & 161 \\
\hline 73 & 122 & 153 & 88 & 69 & 70 & 70 & 184 & 163 \\
\hline 74 & 109 & 66 & 136 & 135 & 144 & 132 & 41 & 165 \\
\hline 75 & 116 & 137 & 11 & 132 & 18 & 148 & 105 & 169 \\
\hline 76 & 159 & 82 & 140 & 24 & 132 & 18 & $\underline{\text { IT059 }}$ & 173 \\
\hline 77 & 140 & 141 & 44 & 85 & 135 & 6 & 69 & 175 \\
\hline 78 & 83 & 163 & 138 & 45 & 45 & 135 & 142 & 176 \\
\hline 79 & 99 & 132 & 95 & 53 & 147 & 45 & 29 & 181 \\
\hline 80 & 112 & 67 & 43 & 183 & 148 & 147 & 110 & 182 \\
\hline 81 & 132 & 9 & 57 & 144 & 85 & 55 & 44 & 183 \\
\hline 82 & 178 & 112 & 67 & 83 & 24 & 24 & 137 & AN213 \\
\hline \multirow[t]{2}{*}{83} & - & 150 & 1 & - & - & - & 133 & AEC144 \\
\hline & - & - & - & - & - & - & 112 & - \\
\hline
\end{tabular}

$\mathrm{DRI}=$ degree of rust infection; $\mathrm{NB}=$ number of branches e $\mathrm{DBH}=$ diameter at $1.3 \mathrm{~m}$ height, $\mathrm{SH}=$ Smith e Hazel index $\mathrm{PB}=$ Pesek Barker index e $\mathrm{NI}=$ independent levels.

The commercial clone E. urophylla (AEC144) is an advanced product of clonal breeding program and was used as a reference in productivity and rust resistance; it was a superior material among the best 80 in all selection methods, showing the great potential of this clone. This fact suggests the possibility of using E. grandis hybridization with other compatible species 
and the use of clones in advanced breeding programs. However, as this was the first stage of the species breeding program for sawn logs, it is necessary to maintain the genetic variability between progenies so that it be possible to select and obtain genetic gains in the next stages, which will not be achieved with the use of clones at this stage.

Seedlings of AN213 was found to be the best progenies among the 80 families in three selection methods, direct selection for NB (method 2), DBH (method 3), and method 7. Method 7 was the only method which showed the other seedlings (IT059) among the top 80 genetic materials (Table 8). We can observe that there were families of E. grandis, coming from Atherton, with superior behavior for DRI, NB, and DBH than the two seedling commercial materials coming from Coff's Harbour; suggesting the possibility of using some materials from Atherton instead of from Coff's Harbour.

Method 4 showed similarity between selected families for a DRI of $88.8 \%$, for NB of $50 \%$, and DBH of $70 \%$. For the families selected in method $5,86 \%$ were the same for DRI, $51.3 \%$ for NB, and $71.3 \%$ for $\mathrm{DBH}$. The greatest similarity between the 80 families selected by these methods with the DRI was because of the weighting coefficients of the Smith and Hazel indices prioritized this variable over NB and DBH. Method 6 showed $85 \%$ similarity among the families selected for DRI, $52.5 \%$ for $\mathrm{NB}$, and $70 \%$ for $\mathrm{DBH}$. Method 7 showed $52.5 \%$ similarity between the selected families for $\mathrm{DRI}, 66.3 \%$ for NB, and $78.8 \%$ for $\mathrm{DBH}$. The selection by independent levels (method 8 ) was shown to have the best balance among the families selected for each variable, with $67.5 \%$ similarity between the families selected for $\mathrm{DRI}, 71.3 \%$ for NB, and $68.8 \%$ for $\mathrm{DBH}$.

Table 9 shows percentages of total genetic gains and the new means of the improved population for $\mathrm{DRI}, \mathrm{NB}$, and $\mathrm{DBH}$, at the formation of $\mathrm{SSO}$ in the E. grandis progeny test according to each selection method.

Table 9. Genetic gains (GS total) and new improved means for the degree of rust infection (DRI), the number of branches (NB), and diameter at $1.3 \mathrm{~m}$ height (DBH) with selection between and within E. grandis progenies for the formation of the SSO.

\begin{tabular}{|c|c|c|c|c|c|c|}
\hline \multirow{2}{*}{$\begin{array}{l}\text { Selection } \\
\text { Methods }\end{array}$} & \multicolumn{2}{|c|}{ DRI } & \multicolumn{2}{|c|}{ NB } & \multicolumn{2}{|c|}{ DBH (cm) } \\
\hline & GS Total (\%) & New mean & GS Total (\%) & New mean & GS Total (\%) & New mean \\
\hline Method 1 & 19.39 & 3.60 & 0.75 & 13.16 & 3.43 & 9.37 \\
\hline Method 2 & 2.55 & 2.67 & 6.42 & 10.17 & 1.42 & 8.49 \\
\hline Method 3 & 11.77 & 3.13 & 1.83 & 12.62 & 7.79 & 11.46 \\
\hline Method 4 & 19.47 & 3.60 & 1.81 & 12.50 & 3.73 & 9.36 \\
\hline Method 5 & 19.38 & 3.59 & 2.21 & 12.29 & 4.43 & 9.73 \\
\hline Method 6 & 19.17 & 3.58 & 2.20 & 12.24 & 4.34 & 9.71 \\
\hline Method 7 & 6.74 & 2.91 & 3.88 & 11.64 & 6.70 & 10.99 \\
\hline Method 8 & 13.88 & 3.31 & 4.12 & 11.58 & 5.83 & 10.71 \\
\hline
\end{tabular}

According to Resende (2002a), the fastest way to obtain genetic gains on a given variable is through direct selection on it. The results presented in Table 8 showed that the highest GStotal (\%) for NB and DBH were found with direct selection on these variables. However, for DRI, we observed that similar GStotal $(\%)$ between methods 4, 5, 6, and direct selection. The highest GStotal $(\%)$ estimated by direct selection on each variable was for DRI (19.39\%). This was due to the higher heritability value for this variable concerning NB and DBH where, according to Falconer (1976), the higher heritability, the greater the genetic gain with direct selection.

Also, Resende (2005) comments that when genetic correlation between variables is weak $(<0.50)$, the indirect selection is impaired, as it provides much lower genetic gains than what could be achieved with direct selection, as occurred in this study. The genetic gain calculated with indirect selection was lower than the gains calculated by simultaneous selection methods. Indirect selection for NB and DBH, when the direct selection was practiced on DRI, showed gains of $0.75 \%$ and $3.43 \%$, respectively, far below the gain obtained by direct selection. This fact was also observed when direct selection was done for NB and indirect for DRI and DBH. 
In Table 9 we observed that direct selection on each variable (method 1,2, and 3) resulted in a higher mean of the improved population compared to the three commercial materials used in the progeny test (Table 10), showing the potential for breeding in the selection of E. grandis progenies.

Table 10. Means for the degree of rust infection (DRI), the number of branches (NB), and diameter at 1.3 $\mathrm{m}$ height (DBH) of the three commercial materials used in E. grandis progeny test in Anhembi, São Paulo.

\begin{tabular}{cccc}
\hline Commercial materials & DRI & NB & DBH $(\mathbf{c m})$ \\
\hline IT059 - ASP 2 ${ }^{\text {a }}$ generation - Itatinga-SP & 2.57 & 13.84 & 8.03 \\
AN213 - SSO 1 ${ }^{\text {a }}$ generation - Anhembi-SP & 2.67 & 12.86 & 8.35 \\
AEC144 - E. urophylla clone & 3.56 & 11.72 & 10.71 \\
\hline
\end{tabular}

$\mathrm{ASP}=$ area of seed production

Among the selection indices, the GStotal $(\%)$ were similar for methods 4, 5, and 6. These three methods prioritized DRI, even when the weight established for this variable was smaller (method 5), showing little flexibility in the distribution of genetic gains among variables. This fact was also reported by Paula et al. (2002) with open-pollinated progenies of E. camaldulensis and by Missio et al. (2004) with open-pollinated progenies of Pinus caribea var. bahamensis, in the Smith and Hazel selection indices and they conclude that these indices were inefficient to optimize the gain for all variables simultaneously.

According to Berlin et al. (2010), the use of indices in forest breeding must be following the objectives of the forest improvement program, where the characteristics included in the selection indices must prioritize the most important variables, such as the wood volume for the production of sawn logs in Pinus sylvestris L. method 7 showed the highest genetic gains for NB (3.88\%) and DBH (6.70\%) among the other selection indices. For DRI, the genetic gain obtained by this method was much lower than the possible genetic gain obtained with direct selection, because the coefficient of this index was negative for DRI, and due to the weak genetic correlation with the other variables the genetic gain was unsatisfactory. Selection indices were also used in the study by Cumbie et al. (2012) with 48 progenies of Pinus taeda L.; the authors estimated genetic gains through indices by selecting trees with higher growth and better stem shape for lumber. Unlike this study, the authors observed that the selection index with higher weight for only one variable was the one which best optimized the genetic gain for the other traits evaluated because of high values of genetic correlation (> 0.70).

Method 8 was the one that best distributed genetic gains for the three variables simultaneously, indicating that selection by independent levels could be advantageous when elimination levels are established for each variable, especially when variables present weak correlations between them. The genetic gain for DRI was $13.88 \%$, NB was $4.12 \%$ and DBH was $5.83 \%$. These results show that simultaneous variable selection methods, mainly by independent levels, were more advantageous than indirect selection when an improved material for favorable characteristics at the same time is intended.

Regarding the means of commercial seedling materials used in E. grandis progeny test (Table 10), all simultaneous selection methods (methods 4, 5, 6, 7, and 8) presented means of improved populations higher than commercial materials, indicating a great potential of these selection methods compared to materials from Coff's Harbour. For the commercial clone of $E$. urophylla (AEC144), methods 4, 5, and 6 presented values lower than this clone for the NB and $\mathrm{DBH}$, and methods 7 and 8 presented a lower mean than the clone for the DRI. Due to intense improvement and silviculture, the clone was even better than the selected families of $E$. grandis.

The transformation of the progeny test into SSO will attribute the qualified category for the E. grandis produced seeds (Brasil, 2011). The SSO will be established with selected individuals, with thinning of unselected individuals and isolation against external pollen (Brasil, 2004). This isolation must be done with non-compatible species and at a minimum distance of 250 meters from plantations with the same species (Jones et al., 2008).

In the formation of CSO the effective population size of 50 was considered adequate according to Resende \& Bertolucci (1995); however greater genetic gains are expected due to the higher 
selection intensity between and within families (Oda et al., 1989). The percentages of total genetic gains and the new improved population mean for the implementation of CSO are shown in Table 11.

Table 11. Genetic gains (GS total) and new improved means for the degree of rust infection (DRI, number of branches (NB), and diameter at $1.3 \mathrm{~m}$ height (DBH) with selection between and within $E$. grandis progenies for the formation of the CSO.

\begin{tabular}{|c|c|c|c|c|c|c|}
\hline \multirow{2}{*}{$\begin{array}{l}\text { Selection } \\
\text { Methods }\end{array}$} & \multicolumn{2}{|c|}{ DRI } & \multicolumn{2}{|c|}{ NB } & \multicolumn{2}{|c|}{ DBH $(\mathrm{cm})$} \\
\hline & GS total (\%) & New mean & GS total (\%) & New mean & GS total (\%) & New mean \\
\hline Method 1 & 27.94 & 3.98 & 0.81 & 13.3 & 2.72 & 8.52 \\
\hline Method 2 & 2.69 & 2.70 & 9.44 & 8.42 & 1.99 & 8.47 \\
\hline Method 3 & 11.46 & 3.12 & 2.17 & 12,38 & 10.91 & 13.07 \\
\hline Method 4 & 26.14 & 3.98 & 2.42 & 12.08 & 3.40 & 8.92 \\
\hline Method 5 & 26.40 & 3.98 & 3.05 & 11.60 & 4.59 & 9.73 \\
\hline Method 6 & 25.14 & 3.96 & 3.33 & 11.24 & 4.55 & 9.71 \\
\hline Method 7 & 5.76 & 2.88 & 6.59 & 10.24 & 9.32 & 12.38 \\
\hline Method 8 & 18.76 & 3.60 & 6.72 & 9.86 & 7.23 & 11.41 \\
\hline
\end{tabular}

The estimation of genetic gain for CSO followed similarly to what was estimated for the SSO, where no selection method was as efficient as the direct selection on each variable. For DRI, methods 4, 5, and 6 provided genetic gains very close to direct selection, and methods 2 and 7 were the ones that most penalized the genetic gain for DRI, with an improved mean below 3. Method 7 resulted in greater genetic gain for NB than using other selection indices. The independent selection levels (method 8) showed greater genetic gains for NB, indicating that it is a promising strategy for selecting this variable. For $\mathrm{DBH}$, method 7 presented, among the selection indices, the highest estimate of the genetic gain and the second-best among the proposed selection methods.

As for the SSO, the independent level (method 8) for the CSO was the method that provided the best optimization of genetic gain for the three variables simultaneously, as it was the best for NB, third-best for $\mathrm{DBH}$, with genetic gains of $6.72 \%$ and $7.23 \%$ respectively, and it presented a high genetic gain for DRI (18.76\%), increasing the average of the improved population to 3.60 .

Considering simultaneous selection methods for CSO, the commercial materials IT059 and AN213 presented lower means than the selected E. grandis progenies for all traits. E. urophylla clone (AEC144) presented a superior mean than the improved population in method 7 for DRI; in method 4 for NB; and in methods 4,5 and 6 for $\mathrm{DBH}$. This indicates that among the simultaneous selection methods, the independent level was the only one that provided superior means of the improved population concerning all commercial materials (Table 11).

Through method 8, it is possible to implement a CSO that produces seeds at a good level of genetic improvement for lower DRI, lower NB, and higher DBH. The same method was also the one that best optimized the genetic gain for the formation of SSO. The formation of the CSO will also assign the qualified category of E. grandis produced seeds (Brasil, 2011). CSO must be established through the vegetative propagation of superior individuals and isolation against external pollen (Brasil, 2004). The vegetative propagation technique used should be by grafting. The reason is to maintain the genetic characteristics of the plant and, with appropriate silvicultural techniques it presents ease in the management of pollination (Xavier et al., 2009). CSO should be planted in the most productive location in the area and where the possibility of crossing between related trees is minimal (Mori, 1988).

Due to the weak correlations between variables, the establishment of independent levels (method 8) in the selection for DBH (growth), NB (wood quality) and lower DRI (rust resistance) was the most promising alternative compared to the genetic gains calculated through selection methods and comparison with commercial materials. The independent levels should be the method used to transform the $E$. grandis progenies test in Anhembi, into SSO and CSO, aiming to obtain improved seeds for the three variables in this first stage of the breeding program for sawn logs. 


\section{CONCLUSIONS}

Due to weak correlation between $\mathrm{DRI}, \mathrm{NB}$, and $\mathrm{DBH}$, indirect selection provides a worse optimization of genetic gain compared to the selection indexes and independent levels for SSO and CSO. The independent levels should be the selection method indicated for the formation of seed orchards as it is more efficient in optimizing genetic gains for all traits. Also, independent levels selected superior progeny than seminal commercial materials from Coff's Harbor, indicating that we could find better genetic materials from Atherton. After the recombination of the selected families in the $E$. grandis progeny test, it is recommended to install a new progeny test, aiming to also evaluate other variables for the second stage of the breeding program for sawn logs production.

\section{REFERENCES}

Alvares, C., Stape, J. L., Sentelhas, P. C., Gonçalves, J. L. M., \& Sparovek, G. (2013). Köppen's climate classification map for Brazil. Meteorologische Zeitschrift, 22(6), 711-728. http://dx.doi.org/10.1127/0941-2948/2013/0507.

Balmelli, G., Simeto, S., Marroni, V., Altier, N., \& Diez, J. J. (2014). Genetic variation for resistance to Mycosphaerella leaf disease and Eucalyptus rust on Eucalyptus g/obulus in Uruguay. Australasian Plant Pathology, 43(1), 97-107. http://dx.doi.org/10.1007/s13313-013-0254-7.

Baudouin, L., Baril, C., Clément-Demange, A., Leroy, T., \& Paulin, D. (1997). Recurrent selection of tropical tree crops. Euphytica, 96(1), 101-114. http://dx.doi.org/10.1023/A:1002908918879.

Berlin, M., Lönnstedt, L., Jansson, G., Danell, Ö., \& Ericsson, T. (2010). Developing a scots pine breeding objective: a case study involving a Swedish Sawmill. Silva Fennica, 44(4), 643-656. http://dx.doi.org/10.14214/sf.132.

Brasil. (2004). Decreto $n^{\circ} 5.153$, de 23 de julho de 2004. Texto para impressão Aprova o Regulamento da Lei $n^{\circ} 10.711$, de 5 de agosto de 2003, que dispõe sobre o Sistema Nacional de Sementes e Mudas - SNSM, e dá outras providências. Diário Oficial [da] República Federativa do Brasil, Brasília.

Brasil. Ministério da Agricultura Pecuária e Abastecimento. (2011). Instrução Normativa n56, de 8 de dezembro de 2011. Regulamenta a Produção, a Comercialização e a Utilização de Sementes e Mudas de Espécies Florestais, Nativas e Exóticas, visando garantir sua procedência, identidade e qualidade. Diário Oficial [da] República Federativa do Brasil, Brasília.

Cruz, C. D., Regazzi, A. J., \& Carneiro, P. C. S. (2004). Modelos Biométricos aplicados ao melhoramento genético. Viçosa: UFV.

Calvo, M. C. M. (2004). Estatística descritiva (55 p.). Florianópolis: UFSC - Centro de Ciências da Saúde.

Cumbie, W. P., Isik, F., \& Mckeand, S. E. (2012). Genetic improvement of sawtimber potential in Loblolly Pine. Forest Science, 58(2), 168-177. http://dx.doi.org/10.5849/forsci.09-060.

Eldridge, K. G., Davidson, J., Harwood, C. E., \& van Wyk, G. (1993). Eucalypt domestication and breeding (288 p.). Oxford: Ed. Oxford University.

Falconer, D. S. (1976). Introduction to quantitative genetics. New York: Ed. Roland Press.

Gonçalves, J. L. D., Alvares, C. A., Higa, A. R., Silva, L. D., Alfenas, A. C., Stahl, J., Ferraz, S. F. B., Lima, W. P., Brancalion, P. H. S., Hubner, A., Bouillet, J.-P. D., Laclau, J.-P., Nouvellon, Y., \& Epron, D. (2013). Integrating genetic and silvicultural strategies to minimize abiotic and biotic constraints in Brazilian eucalypt plantations. Forest Ecology and Management, 301, 6-27. http://dx.doi.org/10.1016/j.foreco.2012.12.030.

Hamilton, M. G., Acuna, M., Wiedemann, J. C., Mitchell, R., Pilbeam, D. J., Brown, M. W., \& Potts, B. M. (2015). Genetic control of Eucalyptus globulus harvest traits. Canadian Journal of Forest Research, 45(6), 615-624. http://dx.doi.org/10.1139/cjfr-2014-0428.

Hazel, L. N. (1943). The genetic basis for constructing selection indexes. Genetics, 28(6), 476-490. PMid:17247099. http://dx.doi.org/10.1093/genetics/28.6.476.

Jones, M. E., Shepherd, M., Henry, R., \& Delves, A. (2008). Pollen flow in Eucalyptus grandis determined by paternity analysis using microsatellite markers. Tree Genetics \& Genomes, 4(1), 37-47. http://dx.doi.org/10.1007/s11295-007-0086-0.

Kretschmann, D. E. (2010). Mechanical properties of wood. In R.J. Ross (Ed.). Wood handbook: wood as an engineering material (Chap. 5, pp. 1- 45). Madison: USDA, Forest Products Laboratory.

Macedo, H. R., Freitas, M. L. M., Moraes, M. L. T., Zanata, M., \& Sebben, A. M. (2013). Variação, herdabilidade e ganhos genéticos em progênies de Eucalyptus tereticornis aos 25 anos de idade em Batatais-SP. Scientia Forestalis, 41(100), 533-540.

Miranda, A. C., Moraes, M. L. T., Tambarussi, E. V., Furtado, E. L., Mori, E. S., Silva, P. H. M., \& Sebbenn, A. M. (2013). Heritability for resistance to Puccinia psidii Winter rust in Eucalyptus grandis Hill ex Maiden in Southwestern Brazil. Tree Genetics \& Genomes, 9(2), 321-329. http://dx.doi.org/10.1007/s11295012-0572-x. 
Missio, R. F., Cambuim, J., Moraes, M. L. T., \& Paula, R. C. (2004). Seleção simultânea de caracteres em progênies de Pinus caribaea Morelet var. bahamensis. Scientia Forestalis, (66), 161-168.

Mori, E. S. (1988). Pomares de sementes florestais. Piracicaba: IPEF.

Nichols, J. D., Smith, R. G. B., Grant, J., \& Glencross, K. (2010). Subtropical eucalypt plantations in eastern Australia. Australian Forestry, 73(1), 53-62. http://dx.doi.org/10.1080/00049158.2010.10676310.

Oda, S., Menck, A. L. M., \& Vencovsky, R. (1989). Problemas no melhoramento genético clássico do eucalipto em função da alta intensidade de seleção. IPEF: Instituto de pesquisas e Estudos Florestais, (41-42), 8-17.

Oliveira, T.W.G., Higa, A. R., \& Silva, L. D. (2018). Parâmetros genéticos em teste de progênies de polinização aberta de Eucalyptus grandis Hill ex Maiden. Scientia Forestalis, 46(118), 229-240.

Paula, R. C., Pires, I. E., Borges, R. C. G., \& Cruz, C. D. (2002). Predição de ganhos genéticos em melhoramento florestal. Pesquisa Agropecuária Brasileira, 37(2), 159-165. http://dx.doi.org/10.1590/S0100-204X2002000200007.

Pešek, J., \& Baker, R. J. (1969). Desired improvement in relation to selection indices. Canadian Journal of Plant Science, 49(6), 803-804. http://dx.doi.org/10.4141/cjps69-137.

Polli, H. Q., Reis, G. G., Reis, M. G. F., Vital, B. R., Pezzopane, J. E. M., \& Fontan, I. C. I. (2006). Qualidade da madeira em clone de Eucalyptus grandis W. Hill ex Maiden submetido a desrama artificial. Revista Árvore, 30(4), 557-566. http://dx.doi.org/10.1590/S0100-67622006000400008.

Resende, M. D. V. (2002a). Genética biométrica e estatística no melhoramento de plantas perenes. Colombo: Embrapa Florestas.

Resende, M. D. V. (2002b). Software SELEGEN-REML/BLUP. Colombo: Embrapa Florestas - Documentos.

Resende, M. D. V. (2005). Melhoramento de essências florestais. In: A. Borem (Ed.), Melhoramento de espécies cultivadas (pp.717-780). Viçosa: Editora UFV.

Resende, M. D. V., \& Bertolucci, F. L. G. (1995). Maximization of genetic gain with restriction on effective population size and inbreeding in Eucalyptus grandis. In Cooperative Research Centre for Temperate Hardwood Forestry (Org.), IUFRO Conference Eucalypt Plantations: Improving Fibre Yield And Quality (pp. 167170). Sandy Bay: Cooperative Research Centre for Temperate Hardwood Forestry.

Rezende, G. D. S. P., Resende, M. D. V., \& Assis, T. F. (2014). Eucalyptus breeding for clonal forestry. In T. Fenning (Ed.). Challenges and Opportunities for the World's Forests in the 21st Century (pp. 393-424). Amsterdam: Springer. http://dx.doi.org/10.1007/978-94-007-7076-8_16.

Rodas, C. A., Roux, J., Maier, W., Granados, G. M., Bolaños, M. D., McTaggart, A. R., \& Wingfield, M. J. (2015). First report of Puccinia psidii on Corymbia citriodora and Eucalyptus in Colombia. Forest Pathology, 45(6), 534-536. http://dx.doi.org/10.1111/efp.12223.

Smith, H. F. (1936). A discriminant function for plant selection. Annals of Eugenics, 7(3), 240-250. http://dx.doi.org/10.1111/j.1469-1809.1936.tb02143.x.

Smith, O. S., Hallauer, A. R., \& Russell, W. A. (1981). Use of index selection in recurrent selection programs in maize. Euphytica, 30(3), 611-618. http://dx.doi.org/10.1007/BF00038788.

Vencovsky, R., \& Barriga, P. (1992). Genética biométrica no fitomelhoramento. Ribeirão Preto: Sociedade Brasileira de Genética.

Villanueva, B., \& Woolliams, J. A. (1997). Optimization of breeding programmes under index selection and constrained inbreeding. Genetical Research, 69(2), 145-158. http://dx.doi.org/10.1017/S0016672397002656.

Volker, P. W., Dean, C. A., Tibbits, W. N., \& Ravenwood, I. C. (1990). Genetic parameters and gains expected from selection in Eucalyptus globulus in Tasmania. Silvae Genetica, 39(1), 18-28.

Xavier, A., Wendling, I., \& Silva, R. L. (2009). Silvicultura Clonal: princípios e técnicas. Viçosa: UFV.

Zamprogno, K. C., Furtado, E. L., Marino, C. L., Bonine, C. A., \& Dias, D. C. (2008). Utilização de análise de segregantes agrupados na identificação de marcadores ligados a genes que controlam a resistência à ferrugem (Puccinia psidii Winter) em Eucalyptus sp. Summa Phytopathologica, 34(3), 253-255. http://dx.doi.org/10.1590/S0100-54052008000300009.

Authors contributions: TWGO: Writing - original draft, Data curation, Formal Analysis, Investigation; ARH: Writing - review \& editing, Investigation, Conceptualization; LDS: Writing - review \& editing, Investigation, Conceptualization; Resources. 